

\title{
Institutions and bureaucracy in brazilian scientific and technological policy ${ }^{1}$
}

\author{
Instituições e burocracia na política científica \\ e tecnológica brasileira
}

Daniel Francisco Nagao Menezes*

\begin{abstract}
We present an analysis of the institutional and political trajectory of Brazilian initiatives in science, technology and innovation, starting from the creation of CNPq, with emphasis on the internal dynamics of the Statedescribing the context and the institutionalization dynamics of the sector packed by the developmental diagnoses and the renewed prestige of "science" typical of those years. The purpose of the analysis is to verify known results from the literature on state, institutions and actors in Brazil and to base empirical research on the executive power in this policy field. The interpretation of the data was oriented in order to reconstruct the trajectory of the sector focusing on the internal dynamics of the decision arena and its political constraints. The results confirm theoretical generalizations of the Executive Power literature in Brazil, such as the centrality of personal contact networks in the implementation of policies in the 1960 s and 1970 s.
\end{abstract}

Keywords: Executive power; actors and institutions; bureaucracy and politics; science, technology and innovation; CNPq.

\begin{abstract}
Resumo
Apresentamos uma análise da trajetória institucional e política das iniciativas brasileiras em ciência, tecnologia e inovação, a partir da criação do CNPq, com ênfase na dinâmica interna do Estado, descrevendo o contexto e a dinâmica de institucionalização do setor embalado por os diagnósticos de desenvolvimento e o renovado prestígio da "ciência" típico daqueles anos. $O$ objetivo da análise é verificar resultados conhecidos da literatura sobre estado, instituições e atores no Brasil e basear a pesquisa empírica no poder executivo nesse campo político. A interpretação dos dados foi orientada a fim de reconstruir a trajetória do setor, enfocando a dinâmica interna da arena de decisão e suas restrições políticas. Os resultados confirmam generalizações teóricas da literatura do Poder Executivo no Brasil, como a centralidade das redes de contatos pessoais na implementação de políticas nas décadas de 1960 e 1970.
\end{abstract}

Palavras-chave: Poder executivo; atores e instituições; burocracia e política; ciência, tecnologia e inovação; CNPq.

\footnotetext{
* Master and PhD in Political and Economic Law (Universidade Presbiteriana Mackenzie, São Paulo). Post-Doctor in Law (FADUSP, Faculty of Law, University of São Paulo). Professor of the Graduate Program in Political and Economic Law at the Faculty of Law, Universidade Presbiteriana Mackenzie. Member of CIRIEC-Brasil (Centro de Estudos e Pesquisas em Economia Pública Social). https://orcid.org/0000-0002-7755-3063.

E-mail: nagao.menezes@gmail.com
} 


\section{INTRODUCTION}

The most recent theories on the dynamics of public policy have stated that they may go through long periods of stability or may change rapidly. One of the most widespread analytical frameworks for policy analysis today, the punctuated equilibrium theory, considers that public policy subsystems are homeostatic. This means that they have a regulating mechanism capable of keeping their output stable or modifying them radically and rapidly to adapt to pressures arising from interaction with their external environment. This is because the effects of policy implementation on the environment affect the internal dynamics of the subsystem through negative and positive feedback action (BAUMGARTNER \& JONES 2002; 1991; JONES, BAUMGARTNER \& TRUE, 1998).

Paul Pierson sharply criticized homeostatic approaches when he advocated considering the historical trajectory of policies for consistent analysis. According to the author, focusing on the dramatic moments of change ultimately neglects the importance of what happens before and after them. Another aspect of the criticism was that those models disregard the possibility that substantive changes occur slowly: "The fact that something happens slowly does not make it unimportant" (PIERSON, 2005, p.40). Pierson's recommendation requires that methodologically, stability analyzes and policy changes be carried out under detailed reconstitutions of his trajectory with respect to the internal dynamics of his institutional and political aspects. Authors from the field of science, technology and society in Brazil have drawn attention to the strong paradigmatic stability that characterizes the decision-making process of Brazilian science, technology and innovation policy (S\&T, CT\&I or PCTI policy - see abbreviation list at the end) (Dagnino 2007). This important result, combined with the theoretical debate on homeostatic policy subsystems, motivates an analysis of the trajectory of the Brazilian PCTI with an emphasis on the structure of internal state processes. This task joins the effort of a research community that since the late 1990s has been developing detailed analyzes of the mechanisms that internally structure the decision-making arenas of the executive branch (FIGUEIREDO 2004; MARQUES 2006; D'ARAUJO 2009; BORGES, 2010).

The work of reconstructing the institutional trajectory of Brazilian ST\&I policies, focusing on the internal dynamics of the state, is a step towards grounding empirical research on the executive power in this field of public policies. Their bodies have characteristics similar to those responsible for monetary and economic policies, for example, such as the high degree of isolation and institutionalization. Empirical research such as those already carried out for the Central Bank (OLIVIERI, 2007) and the Ministry of Finance (LOUREIRO, ABRÚCIO \& ROSA, 1998) cannot disregard a review of the trajectory of the state's internal dynamics in the sector.

This article, however, has its own objective, which is to verify known results of the Executive Power literature in this policy field: to investigate the role of personal contact networks and the dynamics of bureaucracy isolation for the realization of 
policy models. Which are either still in place or have a decisive influence on current diagnostics and implementation tools. Ben Schneider initially verified the prevalence of personal contacts in the mechanisms that gave stability and effectiveness to the developmental policies of the 1970s in his analysis of the bureaucracy and Brazilian industrial policy in the military regime (SCHNEIDER, 1994). Eduardo Marques showed how the internal groups of the bureaucracy are able to structure the interior of the state: the level of negotiation that the political groups invested with the institutional power will be forced to engage with groups of the bureaucracy depends on their strength and prestige and the degree of isolation of the state organizations involved (MARQUES, 2006).

Some authors have already sought to describe a trajectory of S\&T in Brazil: by periodizations that highlight the life and work of prominent scientists located in their institutional and historical contexts, or by trajectory descriptions of policy implementation programs and instruments (SCHWARTZMAN, 1979; 2001; BALBACHEVSKY, 2010). In addition to these pioneering efforts, our descriptive emphasis is intended to contribute new elements to the discussion. For the reconstitution of the political-institutional trajectory of the Brazilian ST\&I arena after World War II, we used secondary data from works of historiographic bias such as Campos Muniz (2008), which recorded the "oral history" of CNPq by collecting more than 30 interviews with technicians and former Council directors who served on the board between the 1970's and 1990's; Albagli (1987), who compiled the trajectory of laws, decrees and other legal instruments that introduced changes in the institutional format of the CNPq's operation until 1974; Marques (1992), who reports the history of Brazilian nuclear policy; Vieira and Videira (2007), who present the history and historiography of physics in Brazil, Moreira (2014), which describes the tensions between the authoritarian regime and the community of physicists; and Videira (2010), which discusses the historical background of the Ministry of Science and Technology. Other reports such as Guimarães (1995), which analyzed the trajectory of the technological development policy until the early 1990s, and Ferrari (2010), which reported BNDE's actions in S\&T between the 1960s and 1970s, constituted important sources of information about the decision-making process in ST\&I in Brazil. We also consulted the CNPq general archive in Brasilia, where we had access to minutes of Deliberative Council meetings dating back to the 1950s and other documents.

\section{THE INSTITUTIONALIZATION OF THE BRAZILIAN ST\&I SUBSYSTEM: FIRST PHASE}

The institutionalization of the CT\&I (PCTI) policy in Brazil took place in the post-World War II context, with the creation of the CNPq in 1951. By this time, the foundational foundations of the modern Brazilian state apparatus were already laid. It is also at this point that the providers of the cognitive foundations of the Latin 
American developmental project were beginning to realize that achieving economic development solely through capital accumulation would be a thankless task to pursue. Technological development was beginning to gain ground as an argument of necessity for the strategic policy of the modern developmental state.

The moment of CNPq's creation was marked, at the international level, by the institutionalization of a policy paradigm for the area of S\&T. The Bush Report, prepared by Vannevar Bush and presented to then-US President Franklin Roosevelt at the end of World War II, is considered a milestone in the institutionalization of a S\&T policy model whose decision-making arena was politically centered on scientists (BUSH, 1945). . The model, which would become paradigmatic and known as science push, marked the initial moment when government planning in S\&T was gaining a privileged place in the political agenda of governments. The period known as the "Big Science Era", which runs from the end of World War II to the late 1970s, was characterized by the existence of large projects and steadily growing budgets for S\&T activities. The role of scientists in this policy paradigm goes beyond the exercise of cognitive authority; they act as political regulators of the decision-making process, defining both the thematic development agenda and implementation strategies. This performance was supported by normative propositions for the functioning of scientific activity such as Robert Merton, who affirmed neutrality as ethos of science and scientist (VELHO, 2011).

Internally, there was a dynamic that put on opposite sides groups of the scientific community linked to the Brazilian Academy of Sciences $(A B C)$, based in Rio de Janeiro, and groups based in the state of São Paulo. This dynamic explains the context of the founding of the Brazilian Society for the Progress of Science (SBPC), in 1948, which even claiming to be a "national society, without political or religious color", almost exclusively records the presence of researchers from other institutions. From the state of São Paulo (besides entrepreneurs and professionals from the technological sectors). The background of this obvious antagonism was the political context of the period prior to the democratization of the 1940's period. SBPC was founded by paulistas in the context of the re-democratization of the post-World War II period, and has remained linked to research institutions in São Paulo for several decades.

The SBPC was founded on policy guidelines that sought to broaden the scope of S\&T debates. Admission to his paintings was not exclusive to scientists; his founding minutes record the signature of a "farmer", for example. His proposal, it seems, was to become an entity recognized by broad sectors of society as a legitimate representative of social demands for S\&T, which would make it more politically advantageous than the traditional Brazilian Academy of Sciences ( $A B C)$, given its aristocratic and conservative profile, in the context of the democratic opening of the 1940s. ABC was not an entity capable of representing the different interests on the S\&T agenda that already occupied the attention of different sectors of Brazilian society at that time. SBPC had 352 members a year after its founding and adopted free admission to its 
staff, while ABC limited its membership to 100, always acting privately with respect to new admissions.

The conflicts surrounding the first institutional phase of the Brazilian PCTI, and which had a lasting influence on it, were strongly influenced by this national and international context. CNPq's first president was a naval school officer who had also presided over ABC. Admiral Alvaro Alberto da Mota e Silva represented Brazil at the United Nations Atomic Energy Commission meetings during the 1940s. He was therefore involved in discussions on nuclear technology in the immediate postwar period. This previous experience marked his political positions on Brazilian technological autonomy in the nuclear sector. However, the creation of the CNPq also had the support and intense involvement of the nuclear physicist's community, mostly linked to the University of Sao Paulo, who had close ties with their US counterparts who took part in the war efforts. They knew the prestigious environment in which physicists in that country lived, and intended to emulate such an environment in Brazil by reproducing the institutional foundations of the science push model.

However, the appointment to the CNPq presidency of a naval officer aligned with positions advocating autonomous nuclear technology development created two potential friction zones with the scientific community. The first, because the science push model foresees the transfer of both the material power and the symbolic power of S\&T policy to scientists, which was not the case in Brazil. In the US, physicist Alan Waterman, who had previously lectured at Cincinnati and Yale universities, first served the newly created National Science Foundation. The second, because after the use of nuclear artifacts in Japan, came the general inclination of the community of physicists, even some who participated in the war effort, to positions contrary to their proliferation (ROSA, 2005). Brazil was already recognized as possessing vast and important deposits of atomic ores, and the important political decision that lurked behind the scenes of power was whether to become an exporter of these ores or to develop technology for their use. It was in this context that foreshadowed the conflicts that marked the institutionalization phase of the Brazilian State's activities in the S\&T sector, that Álvaro Alberto began the creation of the CNPq and the structuring of its bureaucracy.

The body was created under the name of "National Research Council" by Law No. 1310 of January 15, 1951, as "a legal entity reporting directly and immediately to the President of the Republic". The founding law expressly provided for its "technicalscientific, administrative and financial autonomy" and referred to a regulation the definitions of the forms of admission, the work regime and the duties of its staff, although it already guaranteed the prerogative of admitting, "Staff not characterized as permanent". The regulation on personnel standards followed shortly, in the form of Decree No. 29,433 of 4 April 1951. It contained the categorization of Council staff as "scientific, technical, teaching and administrative". It was anticipated that the chairperson should appoint teaching staff, and public servants required under current law would staff that entire administrative staff. 
Thus, Álvaro Alberto was able to rely on the staff of scientists and technicians he trusted, as well as having administrative staff with experience working in other public administration bodies. Regarding the profile of Álvaro Alberto's bureaucracy, we know that the presence of engineers in the leadership posts and in the composition of the Deliberative Council was dominant. There was also the presence of nuclear physicists, such as César Lattes and Bernhard Gross, experienced military personnel and politically connected civil servants. They also formed the first generation of bureaucrats and policy makers in Brazil's S\&T sector.

We argue that the intensity of the political debates of those times and their thematic focus, which brought S\&T policy to the center of the discussions now, helped in the rapid formation and cohesion of the internal groups that structured the agency's work. The broader political environment at the time opposed two blocks of actors who held opposing positions on how to combine international relations and economic development. On the one hand were those who advocated greater alignment with the relational dynamics formulated by the US, on the other, those who advocated positions of independence and economic and technological autonomy. This debate marked the first moments of the institutional isolation of the Brazilian PCTI led by the "nationalist" Álvaro Alberto, during the early 1950s.

Supported by the military and the engineering sector of the scientific community, which at the time were leading these activities in Brazil, Alberto opposed the guidelines issued by the Ministry of Foreign Affairs on the policy of exporting atomic minerals and the acquisition of nuclear technology. Cervo \& Bueno (1992), in their widespread history of Brazilian Foreign Policy, reported on the political context and an important fact that supports the suggestion of the rapid cohesion of internal groups and illustrates the nature of CNPq's isolation at that time: The Council, contrary to the agreements signed by the Brazilian government with the US, would have quietly negotiated with German companies to buy three uranium enrichment ultracentrifuges in January 1954.

The groups that at that time internally structured the CNPq were mostly composed of professional bureaucrats, military personnel, and engineers who made up the scientific community of the time. They were fundamental references in the intense debates on the use of atomic minerals that were reflected in the government itself and in Congress. They enjoyed a high degree of isolation and autonomy, which left them in the position of leading political clashes of great relevance. They were deeply involved in one of the chapters of the political conflict that culminated in Vargas's suicide. The authors also note, "with the rise of Café Filho, the difference in view of the atomic question between the CNPq and Itamaraty would be accentuated" (CERVO \& BUENO, 1992, p.283).

The position of the allied political groups of the internal groups formed in the newly created Brazilian PCTI institutional structure did not prevail after the change of government in the mid-1950s. Álvaro Alberto eventually resigned his post as president of the CNPq in March 1955. As a result, many changes were made to the composition 
of the Deliberative Council, the board of directors and the office of the president of CNPq. The events that occurred during the political disputes led to the first institutional change after the establishment of its bases in 1951. The National Security Council removed from CNPq the prerogative to act on matters involving nuclear technology, which was transferred to the National Energy Council. Nuclear, created by Decree No 40.110/56. Groups aligned with the nuclear technology procurement strategy were cut off from policy and the agency's budget declined, along with the prestige of its bureaucracy.

\section{THE SECOND PHASE OF INSTITUTIONALIZATION}

Shortly after the conflicts that set the structure of CNPq, its actions were oriented towards the promotion of research, focusing on support for the formation of personnel. These guidelines were in line with the diagnoses from the then National Bank for Economic Development (BNDE), which identified the additional investments of the Brazilian economy to import technology as a vulnerable point that had to be resolved. Jayme Magrassi de Sá and José Pelúcio Ferreira, who, considering that there was a strong demand for technology in the productive sectors, proposed a solution that aimed to build endogenous capacity to satisfy it, directed the Bank's actions in the S\&T sector.

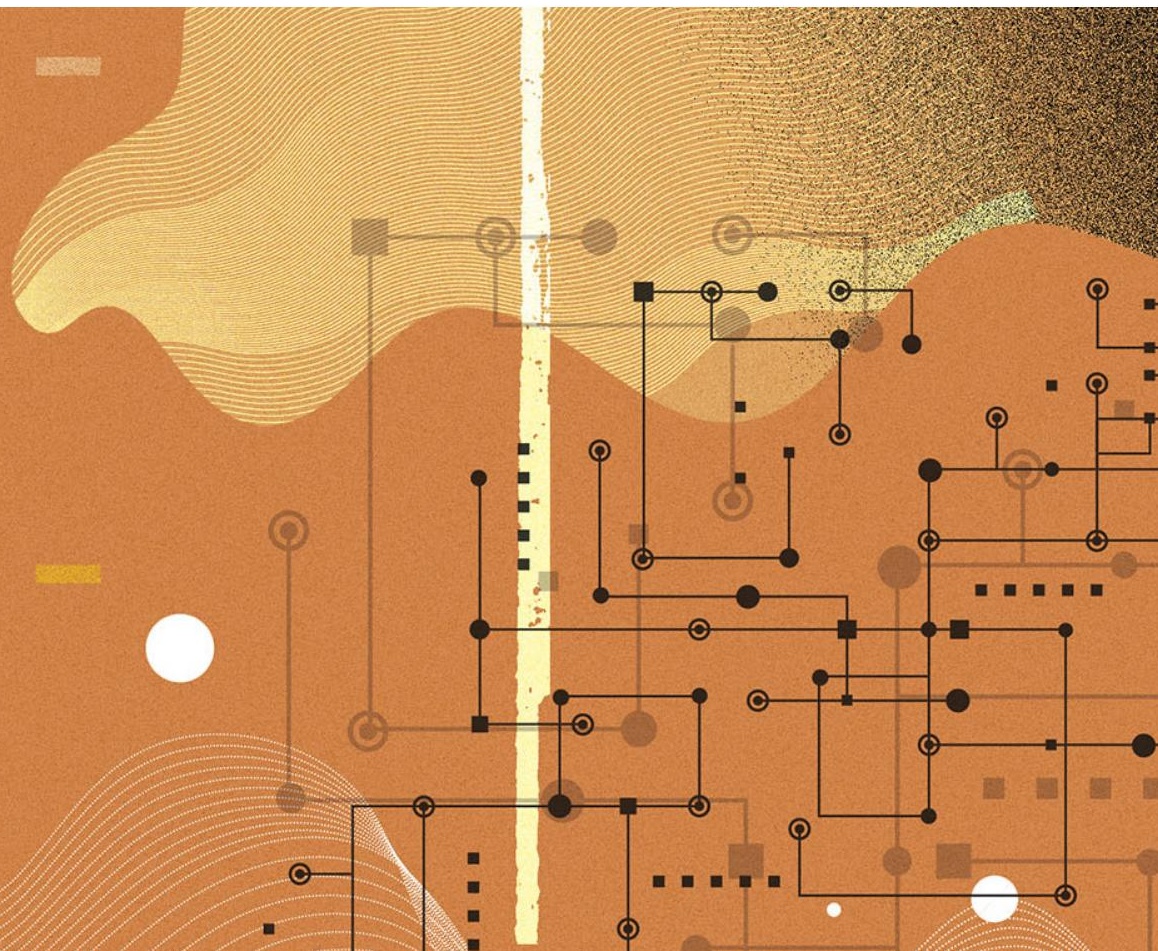


Initially tested on an experimental basis, the first proposal came with the approval of BNDE Resolution No. 46/1958, which established the so-called "Education and Technical Training Quota", an action instrument for the technological development of the industrial sector aimed at the training of staffhigh level technicians in the Brazilian industry. Ferrari (2010), in his account of BNDE's actions in S\&T during this period, recalls that the results of this program were not initially exciting: "[...] of the operations approved until August 1963, only 15 had been contracted, benefiting 11 industrial companies, 3 electric companies and 1 railroad; of these, only 3 made withdrawals to the "Cota de Educação" account, and only 1 depleted the credit granted to it "(FERRARI, 2010, p.301).

Even with the unsatisfactory results of the pilot project, BNDE expanded the initiative of the "Education and Technical Training Quota" program. José Pelúcio Ferreira was inspired by an article by José Leite Lopes, a prestigious physicist and director of CNPq, entitled "National Training and Research Centers for Brazilian Development" published by Tempo Brasileiro magazine in 1962 to propose BNDE Resolution No. 146 / 1964, which created the FUNTEC (Technical-Scientific Development Fund), intended to support postgraduate courses in the fields of Engineering and applied research in the basic industry (Ferrari 2010). FUNTEC resources had their application defined as follows:

"40\% (quarenta por cento) serão destinados à manutenção de Cursos de PósGraduação para a formação de Mestres em Ciências e Doutores em Ciências nos seguintes campos: Física; Química e Engenharia Química; Engenharia Metalúrgica; Engenharia Mecânica e Engenharia de Eletricidade" e "60\% (sessenta por cento) serão destinados às Pesquisas Técnico Científicas, entendendo-se como tais os programas, projetos piloto e experimentações Técnico-Científicas no campo das indústrias básicas" (FERRARI, 2010, p.301).

The difficulties of implementing the "Education Quota" pilot project were eventually overcome by FUNTEC: in 1964 only one project was contracted, this number increased to 7 in 1965, 8 in 1966, 14 in 1967 and 25 in 1968. Personal Contacts Bank bureaucrats and members of the university scientific community helped both to publicize the funding mechanism and to calibrate it to meet the demands of this sector. Ferrari gives us an example of how these contacts worked in part of his account:

"Lindolpho de Carvalho Dias, Diretor do Impa [Instituto de Matemática Pura e Aplicada], soube da existência do Funtec por intermédio de Coimbra [Alberto Luiz Coimbra], a quem ele encontrava na Universidade. Foi levado ao Banco por Paulo Vieira Belotti, Engenheiro da primeira leva do BNDE e amigo de Pelúcio e que tinha sido colega de Escola de Engenharia de Lindolpho. Levaram junto John Milne Albuquerque Forman, professor de Geologia, e amigo comum. Tiveram uma primeira de várias conversas em que puderam defender a importância da inclusão de Matemática e de Geociências entre as áreas que poderiam receber apoio do Funtec" (FERRARI, 2010, p.311). 
The tensions that could exist between the CNPq and BNDE bureaucracy groups were circumvented through the established personal contacts. They were instrumental in enabling coordination among the agencies involved in the implementation of the program. An important example of the coordinated action between these bodies was when BNDE, from 1969, began to release resources only for postgraduate programs that were recognized by CNPq. Shortly afterwards, the percentage quotas for the application of resources (40\% for postgraduate courses and $60 \%$ for technical and scientific research for industrial application) were matched, and the thematic fields of postgraduate courses that could receive funding from the FUNC. Personal contact networks were fundamental for the coordination of actions and the establishment of consensus, enabling the effectiveness of the application of resources, which overcame the difficulties encountered for the pilot program of the late 1950s.

While these contacts ensured the quantitative results of applying FUNTEC, they also eventually became the cause of what Carlos Pacheco would later call "the fragile part of the model and its weakness" (PACHECO, 2003, p.9). This was because, with coordination, the parameters that graduate programs should follow were dictated by the scientific community of "hard sciences" and not by the real problems demanded by the "shop floor" of industrial sectors. This eventually reinforced the cycle of sustaining research funding that was in fact exogenous to the economic and social needs that BNDE bureaucrats intended to overcome by training masters and doctors in areas considered strategic. The signs of relevance and quality of research, which should, by the rationality of the BNDE, be aligned with the demands of the industrial base, were aimed at meeting the agendas of the big institutions and corporations of the then vice-politics of big science implemented mainly in the USA. The most prodigious Brazilian "hard science" scientists of the time, who had access to the CNPq's decisionmaking arena, kept close contact with the big science agenda. Mario Schenberg, José Leite Lopes, Oscar Sala, Cesar Lattes, Jayme Tiomno, Marcelo Damy and others are examples of this (VIEIRA \& VIDEIRA, 2007).

Big science politics was more than just CT\&I politics: the term was coined by Derek de Solla Price in Little Science, Big Science as the synthesis of a US government-led S\&T strategy until the late 1970s (SOLLA PRICE, 1963). Big science was a state strategy whose objective was to guide the research agendas of the scientific communities of Latin America. This objective was important in order to broaden its capacity to face the political and ideological dispute that the United States played with the Soviet Union.

Analyzing databases of scientific publications, Solla Price found that $25 \%$ of researchers produced $75 \%$ of scientific articles in the "hard sciences" area in the US. For him, this would be the manifestation of something like a law of diminishing returns for state investments in S\&T. His argument was that every society would have a limited number of individuals especially qualified for scientific, sporting, and artistic, among others. This would explain the concentration of articles in a restricted portion of the scientific community. Once the contingent devoted to the effective performance 
of those activities is reached, the incorporation of more individuals would imply diminishing returns on investments.

The author then stated that the US had already reached the limit of efficient constitution of its scientific community. To insist on the endogenous increase of individuals who would take part in US scientific activities of the 1960s would mean losing the efficiency of state investment returns. The solution would then be to establish a strategy that could introduce relevant topics of technological development of US interest into the agenda of research communities in Latin American countries, for example, in which the formation of these communities was still far from reaching a considerable degree maturity. In short, the endogenous technological capacity building effort of the Brazilian industry projected by the BNDE also ended up contemplating the endogenous capacity expansion strategy of the US technologicalindustrial-military complex.

It is during this period that international cooperation initiatives for the development of Latin American countries such as those of the "Alliance for Progress" (USAID) and the Inter-American Development Bank (IDB) began to contribute resources to scientific and technological infrastructure projects (Derenusson, 2011). In Brazil, these external sources of funds were accounted for in a fund created in 1965: the Program Project Finance Fund, operated by BNDE, which two years later was transformed into the Public Financing Company for Studies and Projects, FINEP. Supported by the FUNTEC implementation model, Planning Minister João Paulo dos Reis Velloso proposes the creation of the National Fund for Scientific and Technological Development (FNDCT) in 1969. From 1971 FINEP, chaired by FUNTEC mentor José Pelúcio Ferreira, becomes the Executive Secretariat of the FNDCT.

The institutional and cognitive foundations that were then consolidated in the Brazilian PCTI were at their very birth very specific: what in other countries could be identified as science push or demand pull policies and programs, the first focused on supporting the agenda formulated by scientists and the second in economic and social demands, in Brazil became part of a project strongly centered on the bureaucratic rationality of an insulated planning. One aspect that has limited the success of this centrality bias is that the qualitative objectives that underlie the diagnoses have become less important than meeting the quantitative goals of their execution.

The political environment of the 1970's and the very deepening of the centrality of insulated bureaucratic planning eventually laid the foundations of a policy paradigm whose institutional and discursive foundations are openly oriented toward the satisfaction of demands, but its cognitive foundations project action and interpret the reality by the logic of the science push model. 


\section{THE GOLDEN AGE OF S\&T BUREAUCRACY}

With the resurgence of the authoritarian regime in the late 1960s, the institutional environment linked to S\&T activities entered what we consider its third phase of the political-institutional trajectory. The normative measures of the previous period have been reinvigorated with the introduction of new funding mechanisms for the implementation of an S\&T policy that should remain in line with priorities and demands. FUNTEC's implementation model inspired the creation of the National Fund for Scientific and Technological Development (FNDCT) initially operated by FINEP. This period will record the uplift of CNPq as the central organ of PCTI. This was because, in addition to the structuring measures of implementation, measures were taken that promoted the institutional remodeling of the S\&T subsystem, as was the case with CNPq and universities (Balbachevsky, 2010).

In this phase, some normative measures were intended to restructure the institutional foundations that set the policies of the previous period. Although commonly marked by the authoritarian bias that characterized the political environment at the time, they were clothed with modernizing senses. This is the case of the University Reform Law (Law $N^{\circ} 5.540 / 68$ ), which promoted changes in the institutional functioning of universities, creating, for example, the department as "the smallest fraction of the university structure", which ended the chairs in a attempt to disarticulate the political groups that hegemonized the university spaces and were critical of the authoritarian regime.

At the same time, institutional changes were promoted in CNPq that would contribute to the resumption of its leading role in S\&T policy. Decree No. 65.499 / 69 instituted the regulation of its staff, which consolidated the institutionalization of the technical-scientific and administrative careers linked to the body. This moment marked the reestablishment of the cohesion of the bureaucracy's internal groups, which contributed to the beginning of a new period of isolation that kept university professors and members of the scientific community from their decision-making spaces. In this phase, the foundations of the identity and the commitment that the bureaucracy's internal networks would devote for a long time to the organ, which also gained a new legal format and new attributions, were established. These included the prerogative of "formulating and updating the policy of scientific and technological development", thus rescuing the protagonism and prestige of the agency of the first half of the 1950s.

The political defeat of the internal groups of the 1950s was compensated in the 1970s precisely because they identified the same "nationalist and developmentalist" values that discursively propelled the military regime. In the 1950s, the part of the scientific community that opposed Almirante Álvaro Alberto's nuclear technology project took over the political direction of the S\&T sector by directing its actions towards staff training, which helped them in the internal dynamics of university policy 
and in structuring of graduate programs. Now the political game had changed: the scientific community groups that had gained prestige in the previous period were persecuted and their lives made difficult by the authoritarianism of the political regime. Meanwhile, internal groups in the S\&T bureaucracy were returning to the arena of prestigious decision-making, enjoying considerable autonomy from the university scientific community.

With Law No. 6.129/74, the former "National Research Council" would be renamed "National Council for Scientific and Technological Development", a name that remains today, constituted as a private law foundation linked to the Secretariat of Planning of Presidency of the Republic. The body assumed the coordination of the National Science and Technology System (SNDCT) created years before by Decree No. 70.553/72. The management of engineer José Dion de MeloTeles, a cadre of the technology bureaucracy between 1974 and 1979, is considered the highlight of the resumption of the decision-making centrality of the S\&T bureaucrats for the developmental project of the military regime (CAMPOS MUNIZ, 2008). Throughout this period, the agency, in general, and José Dion in particular, receive political support from the Minister of Planning of the Presidency of the Republic, João Paulo dos Reis Velloso, a devotee of bureaucratic planning.

The consensus model established between the BNDE bureaucrats and the scientific community that then ran the CNPq around the execution of FUNTEC no longer worked so smoothly. The broader political context, with the escalation of political repression, has also contributed to the isolation of the university scientific community from the decision-making processes of S\&T policy. These facts were fundamental in that for a long time, in the imagination of the Brazilian university environment of "hard sciences", research oriented by demands and priorities were inexorably associated with conservative or obscurantist political choices and sectors of society, while research labeled "pure" were immediately associated with critical, emancipating, and progressive choices and behaviors.

An example of the kind of conflict that has emerged between S\&T bureaucrats and university scientists is the nuclear agreement between Brazil and Germany, signed in 1975. Representative bodies such as the Brazilian Society orchestrated the reaction of the scientific community for the Progress of Science (SBPC) and the Brazilian Society of Physics (SBF). The protests were directed to the CNPq, which would not have adopted consultation procedures and would not have called on the community of nuclear physicists to discuss the issue (MOREIRA, 2014). The fact is that the institutional political memory housed within the internal groups of the S\&T bureaucracy blocked the participation of this community of scientists: 20 years after Álvaro Alberto's resignation from the CNPq presidency, it was the scientific community, especially that of physicists, which was now isolated from politics.

Although isolated from the decision-making arena, the research agenda of the university scientific community was still heavily funded by the policies being 
implemented. The diagnosis that postgraduate training had to be supported, which implied supporting scientists' autonomously proposed research guidelines, already affected internal dynamics: quantitative implementation targets were achieved in programs that funded scientists., which generated, in a second moment, more demand on the resources available for this type of action. This mechanism would eventually establish links between the sectors of bureaucracy linked to the operationalization of programs and the different sectors and members of the scientific community. An example of this is what happened at FINEP, FNDCT manager, which executed about $80 \%$ of its budget in the areas of scientific development. With the financing crisis of the 1980s and the prioritization of financial support for projects that are in tune with demands, or "applied", as has been said, the practice of "makeup" of basic projects in order to make them appear "applied" "Had been widespread, with the complacency of FINEP staff (GUIMARÃES, 1995).

In 1979, Reis Velloso left the Planning Secretariat to make way for Mario Henrique Simonsen, who, while not exactly a critic of bureaucratic planning, was a recognized mathematician and economist who had contacts and a career in the university sector. He understood that the political direction of the state S\&T sector should be open to the leading role of the scientific community. Thus, José Dion left the presidency of CNPq, and between 1979 and 1980, a renowned mathematician chaired the organ: Maurício Peixoto.

\section{THE NEW REPUBLIC AND THE OLD CONFLICTS}

As the end of the military regime approached, disputes intensified during the first half of the 1980s between groups established in the scientific community, with a political center in the physicist's community, and bureaucracy groups, which included the military, at least command of the central body of the Brazilian PCTI. Mauricio Peixoto's appointment as CNPqchairman in the late 1970s had strong political significance: it was the return of a scientist to the command of the organ, which satisfied the demands of the SBPC and other entities representing the scientific community. Peixoto's management coincides with Simonsen's management at the head of Planning. With the arrival of DelfimNeto in charge of the portfolio in 1980, the dispute, which did not cease during Peixoto's administration, slipped to the side of the bureaucrats: engineer Lynaldo Cavalcanti took over the presidency in an intense backstage frenzy by physicist José Goldemberg, president of the Brazilian Society of Physics, competing for the nomination (CAMPOS MUNIZ, 2008). CNPq's role as the central organ of the PCTI would be exhausted with the end of the military regime and the arrival of the New Republic.

From 1985, with the beginning of the new democratic period, the political coordination and planning functions of CNPq's S\&T sector were shifted to the newly created Ministry of Science and Technology (MCT). While the CNPq was "returned" to 
the scientific community, the political elite of the insular bureaucratic groups in the Council migrated to the new ministry. In the democratizing discourse of that moment is embedded the diagnosis that the country's difficulties in achieving relevant level of technological autonomy, that is, the failure of the policies implemented in the previous period, was due to the political isolation of the decision-making process imposed on the scientific community. The First National Development Plan of the New Republic states that "[...] at the root of the problems faced by the sector is the neglect to which the participation of the scientific community and other segments of civil society has been relegated to the decision-making process decision making".

This context was also marked by the deep financing crisis of the economy. Its impact on the S\&T sector and the political emergence of the scientific community and its entities at the new political moment led to the center of the decision-making arena diagnoses that proposed the institutionalization of the results of the systemic dynamics of the previous period. The policies that were discursively oriented towards meeting demands, funded by the FNDCT, as we have seen, ended up supporting the researchers' autonomous agendas, in a manifestation of what Guimarães (1995) called the "adaptive reaction", which relied on the consent of sectors of the community bureaucracy of S\&T agencies. This, which occurred informally, took concrete shape in the decision-making arena of the 1980s in restructuring proposals that envisaged the allocation of FNDCT resources to agencies such as CNPq and CAPES. Although these proposals did not succeed, the debate around them marked the new environment of S\&T policies that democratization brought: criticism of bureaucratic centrality and insulated planning placed the representative entities of the scientific community, such as the SBPC, as central actors.

The immediate result of this was manifested in the early propositions of the period, which pointed to the suppression of programs or milestones of implementation identified with both demand-driven developmental diagnoses and the centrality of bureaucratic planning. It turns out that the implementation results of the previous period did not displease the scientific community. On the contrary, they reinforced their role and influence on the relational dynamics with the operational instances of the implementing agencies. The political priority of the scientific community was to remove bureaucratic cadres from the top management positions of the agencies. However, in 1985, the broad alliances that shaped the "New Republic" policy framework led to the creation of a central body for the S\&T subsystem: the Ministry of Science and Technology. Its creation had the participation and support of part of the political elite of the S\&T bureaucracy, specifically the one that adhered to the democratizing project. Opposition to the creation of the ministry was evident in the editorials of two SBPC publications, March 1 and June 2, 1985. The fear that the scientific community would be kept on the sidelines of the decision-making arena mobilized this setback (Videira, 2010). 
The cohesion of bureaucratic groups formed in the political hues of the former "National Research Council" and reinforced with high-skilled technicians in the 1970's was gradually weakened. The CNPq, while losing to the MCT its role of coordinator and formulator of the PCTI lost to the Ministry the elite of its bureaucratic staff, and turned to the implementation of programs aligned with the policy-type model science push. The remaining technical staff lost prestige and space in the decision making process. They were isolated from politics because of the military's departure from the political scene and the proximity established with them in the previous period. This dynamic created an internal division in the bureaucratic groups, and during this period, a growing rivalry between the CNPq and the MCT bureaucrats began.

In the late 1990s, research institutes established at the time of the old Council, or linked to it over time, were directly managed by the Ministry, which further weakened CNPq's functions, helping to erode the former cohesion of S\&T bureaucracy groups. On the scientific community side, the picture has also become more complex. With the democratization of the country and the new political dynamics, the competition for institutional spaces was also internalized in this sector. The influence of the new groupings of party politics reorganized the scientific community groups, bringing new circumstances to their political dynamics. The criteria of relevance and quality of research were deepened and generalized from the perspective of "hard science" scientists, who assumed broad control and influence under the direction of the organ.

The Lattes Platform and Lattes Curriculum were institutional innovations of this period that endowed CNPq with an ability to coordinate actions unprecedented in its trajectory. Hall and Taylor (1996) argued that one of the ways in which institutions can affect actors' behavior and build their action coordination capacity is to become a provider of information about actors. Thus, they can minimize the degree of uncertainty about behavior and focus on reciprocal expectations. By exposing relevant information about individual behaviors, institutions drive individuals to rational behavior, favoring the coordination of actions.

These innovations of the 1990's helped to cleave the research community and consolidate the "hard sciences" community, especially that of physicists, as the political elite of the PCTI, as they were the sector that best responded to the signals of institutional coordination that were now emanating of CNPq. Hence the political differentiation that we understand to be analytically necessary between the scientific community and the academic community, due to the differentiated nature of the policy drivers of these communities: on the one hand, the interest groups that permeate the policy of the MCTI, the State S\&T Secretariats and the Promotion Agencies; on the other, the groups that permeate the internal dynamics of the public universities, linked to the trade union and student movement, which are busier with the indications for the central positions of the universities. Although the networks structured within them 
and the very politics and interests that mobilize them have many points of contact, their party closeness and alliances with other civil society interest groups are often different.

With the results of the historic personnel training policy, Brazil has graduated approximately 10,000 new doctors per year. The contingent of new scientists finds a consolidated institutional environment, and for most of them, the institutions of PCTI no longer play the role of coordinator of actions, encouraging rational behavior, as happened in the political remodeling of the sector in the 1990's contingent, PCTI institutions are the providers of symbols, codes, and interpretations related to a certain social identity. For the new generation of Brazilian scientists, more specifically those of the "hard sciences" community, these institutions are the providers of the means of interpreting reality, constituting moral and cultural references for the various individuals, aligning behaviors and even their Preferences.

In the 2000s, the political groups that structure the state's role in the Brazilian PCTI had considerable success in isolating the dynamics of decision-making from the contexts and debates of broader interest. Their isolation from broader politics was made possible with a recurringly wielded discourse of expertise, sometimes to legitimize their protagonist role in decision-making processes that involved controversial issues of broad interest. In this period, the satisfaction of social and economic demands was incorporated into both government and scientists discourse, it seems, much more as a legitimation strategy than as a consistent commitment (Sobral 2009).

\section{PCTI, BUREAUCRACY AND POLITICS: A CONTEMPORARY ANALYSIS}

The creation of the CNPq in the 1950s was marked by the hectic internal context and the new geopolitical configuration at the international level. The decisionmaking arena was marked by intense conflicts arising from divergent ideas about the direction of nuclear policy. After this first phase, which had soon left significant marks on institutional memory, the programmatic consolidation of state actions in the S\&T sector had been lulled by the diagnoses and priorities of national-developmental thinking. Choosing to support graduate programs as a central solution for endogenous technology development was an option that simplified the complexity of the real problem. Contemporary policy analysis theorists (KINGDON, 2002) have discussed the trap of one-dimensional solution to multi-dimensional problems.

Kingdon talks about the multidimensional character of problems: the complexity that typifies social dynamics implies considering multiple aspects to explain phenomena, to describe them and, in the case of public policy, to solve problems. It turns out that it is very common to approach them one-dimensionally through government programs and actions. The choice of BNDE's bureaucracy 
to fund postgraduate programs for training highly skilled industry staff favored a one-dimensional solution. This option disregarded, for example, the necessary coordination of the research agenda, which sponsored technological education with the real demands of the economy's industrial base. Even nowadays, the insertion of doctors is very low in sectors other than education. The debate on the purpose of the country is still current with the maintenance of considerable effort with the formation of masters and doctors: "para que sejamcapazes de gerarnovastecnologias, apenas escolher tecnologias importadas, ensinar novos pesquisadores? Para trabalhar em empresas, no governo, na academia?" (VELHO, 2001, p. 623).

The quantitative success of the implementation of FUNTEC seems to be another case of what Schneider (1994) had already described about the performance of the Brazilian state bureaucracy of the 1960's and 1970's. In the execution of FUNTEC, we identified the approximation of the BNDE bureaucracy with the scientific community through personal contacts. This result, known from the literature on the Brazilian executive branch, had not yet been demonstrated in analyzes of the institutional and programmatic structuring of the S\&T sector. The failure of the program that preceded FUNTEC led to the mobilization of a network of personal contacts between BNDE bureaucrats and members of the scientific community, the former with the intention of demonstrating the validity of their diagnosis by achieving quantitative program implementation goals.

The insistence of BNDE bureaucrats on the FUNTEC execution model was somewhat the result of the broad autonomy that developmental isolation provided to the decision-making process. When professional bureaucracy operates in fields where it has considerable autonomy and stability with respect to social interests, bureaucrats can work to implement policies that meet their ideas and the needs of their careers and organizations (SKOCPOL, 1985; 1995; GEDDES, 1994). Behavioral modeling such as that proposed by the principal-agent theory is quite adequate both to explain the behavior of bureaucrats and scientists. In the structuring of Brazil's technological development programs in the 1960s, information asymmetry, which by the principalagent theory is the foundation of adverse selection and moral hazard, was present in both delegation of the general problem to BNDE bureaucrats as to the relationship they had with scientists.

The policy option ultimately led to the deepening of a one-dimensional solution to the industrial-based technology deficiency, which reinforced years later the demands for funding for research activities mobilized by the "basic" or "pure" research argument. This reinforcement of inputs brought about by the results of policy implementation and leading to the stabilization of outputs is known as negative feedback, a concept in contemporary policy analysis literature brought about by punctuated equilibrium theory (BAUMGARTNER \& JONES, 2002; 1991; JONES, BAUMGARTNER \& TRUE, 1998).

The punctuated equilibrium theory describes policy subsystems as being able to keep their output stable or radically modify them rapidly to adapt to pressures arising 
from interaction with their external environment. This is because policy implementation recursively affects its own inputs, dynamically redefining them through the action of negative and positive feedback. Negative feedback generates the stabilization of policies, are the factors that attract the policy trajectory for permanence and stability. The interests that are organized around implementation, preference satisfaction, and beliefs in diagnostics and causal relationships shape the effects of negative feedback. These effects explain the stability of policies, manifesting themselves in operational standardization, "golden rules", symbols and logic of interpretation. The literature reports the strength of these stabilizing effects in policy areas marked by expertise, and in them the formation of limited participation subsystems is common, which often leads single actors to exert a monopoly on policy (HELLSTRÖM, 2000; HIRSCH $\&$ SHOTTS, 2014).

Positive feedback encompasses the factors that generate instability in the subsystem and its results. Its effects favor the occurrence of changes, policy innovation and the emergence of new institutions. The preponderance of the positive feedback effects on the negative initiates short-lived contexts that make it possible for decision makers to shift their attention to aspects of problems previously overlooked by the implemented solutions. This is what happened in the context of the transition to the new democratic regime in the mid-1980s: political regime change was the context that favored institutional change and innovation. The MCT was created at this historic moment, the entities representing the scientific community assumed a strong role in defining the institutional directions of the PCTI. This conjuncture favored the removal of cadres of the professional S\&T bureaucracy from the spaces of power, won in disputes by members of the scientific community. However, there were no content changes in the policy model because the interests, beliefs and ideas of the scientific community were already satisfied.

Guimarães's report (1995) reproduced an important diagnosis made at that time, presented as the final report of the "Commission of Scientific Societies", debated at the 37th SBPC Meeting in July 1985. On the model of fostering scientific and technological development, we transcribe an excerpt from the author's reproduction:

“Em uma avaliação de conjunto, a organização desenvolvida nos últimos 35 anos deve ser aperfeiçoada, mas sem mudanças drásticas, preservando-se o papel das diferentes agências e seu caráter pluralístico. [...] Muitos dos problemas pelos quais este tem passado se prendem à orientação tecnocrática de algumas Direções, mais preocupadas em 'procurar', 'planejar', 'avaliar', 'administrar', 'acompanhar' e 'coordenar', a atividade científica do que em promover o seu desenvolvimento" (GUIMARÃES, 1995, p.6).

The context of destabilization, the emergence of positive feedback elements, contradicts the perception that there has been no paradigmatic policy change. This brings into consideration Paul Pierson's cited critique of the theory of punctuated equilibrium. Knowledge of the historical trajectory of politics is essential to understand 
why the scientific community criticized the "technocratic orientation" of the decisionmaking process while recommending a "no drastic change" policy. The creation of the Ministry met with strong resistance from this actor, who, although a new political player in decision-making spaces, acted openly conservatively. The very consolidation of the Ministry took place slowly: between 1985 and 1992, the Ministry was extinguished and recreated several times, sometimes as an appendix of the Ministry of Industry, sometimes as a Secretariat linked to the Presidency of the Republic. It was not until 1992 that the Ministry of Science and Technology gained stability as a central organ of the CT\&I sector.

The research effort of the historical trajectory of the Brazilian PCTI and its analysis under the spotlight of broader theoretical frameworks used in different policy sectors, allows for broadening the debate on its programs and agendas. Comparative studies of the dynamics in the CT\&l and other policy sectors can also help streamline analytics and contribute to building broader shared solutions. The theoretical references and the Brazilian tradition in the studies on executive power have much to contribute to the also traditional field of studies on science, technology and innovation policies in Brazil.
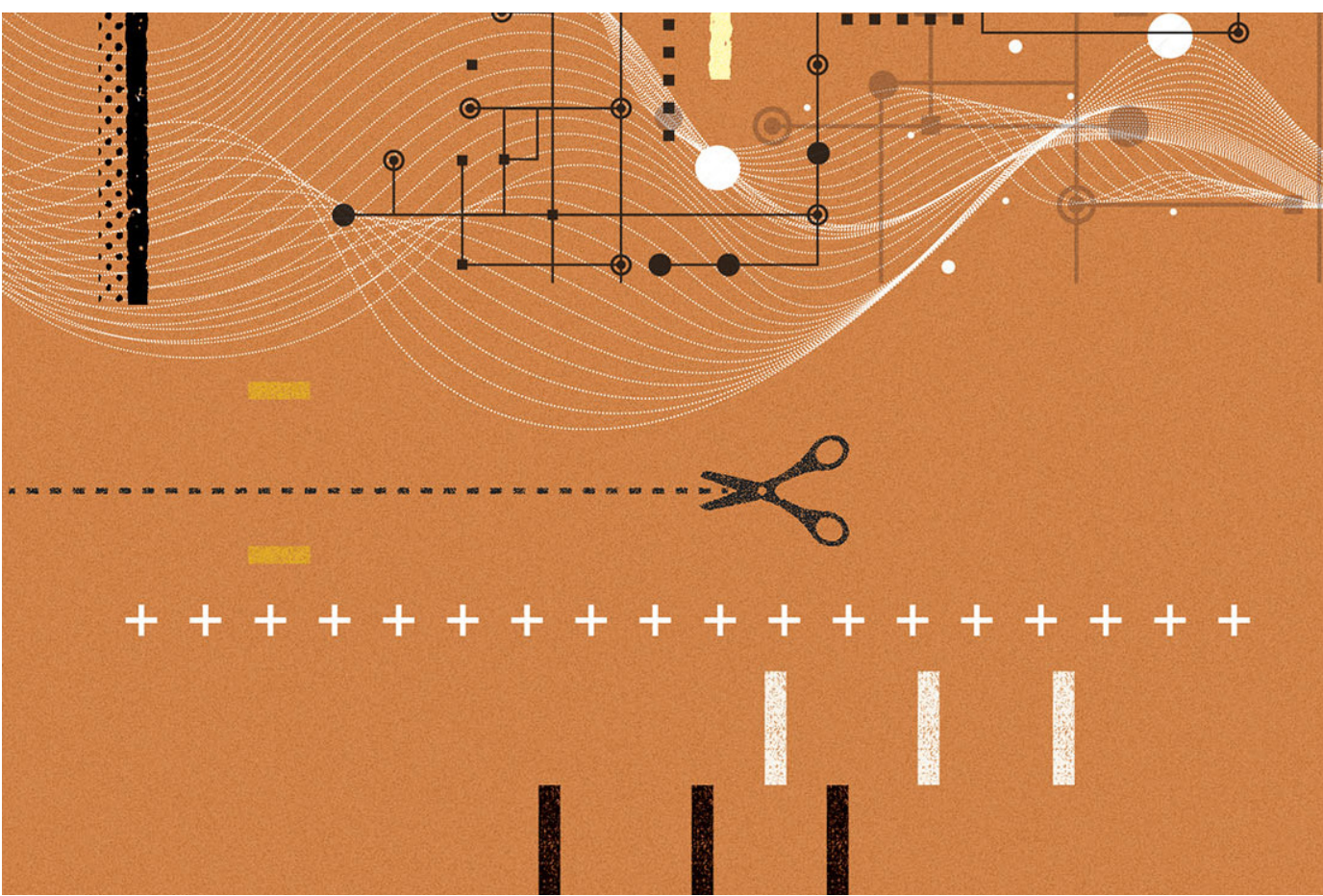


\section{CONCLUSIONS}

Throughout the text, we show that the scientific community of hard sciences has established strong ties with the CT\&l bureaucracy throughout the period of institutionalization of this policy in the country. Personal contact networks were central to the implementation variants that were being adopted: the interest of bureaucrats in confirming their diagnoses and propositions for solution led to the replacement of qualitative policy objectives by the fulfillment of quantitative targets, which would then dominate, relevance criteria for the policy makers since then. The demand for the programs and actions proposed by the implementing agencies and the scale that would denote their relevance came from the scientific community in increasing cadence because it was feedback. Bureaucrats were pleased that they were "right" because the programs under their charge were increasingly in demand, and scientists were pleased to see their research agenda thrive.

The more than 60 years of institutionalized PCTI under the inspiration of the science push model has crystallized beliefs and values about it that are now homogeneously shared in the most diverse arenas: by almost all funding agencies and agencies, by the main groups of party politics, by major media outlets and media and, consequently, by the general public. In Brazil, there has not yet been a significant moment of public criticism of the results of science or of the role of scientists, either in the mold of what has already happened in other countries or in the mold of what might be closer to local needs.

The rejection of arguments of the demand pull paradigm has precedents in the peculiar political trajectory of this sector in Brazil. The political leaders of the scientific community were excluded from the bold decision-making dynamics of the 1970s due to the context of authoritarianism that rocked the country. The university-linked social sectors were disliked by military leaders and commonly associated with the bluntest confrontations the authoritarian regime suffered. This seems to have been one of the moments of the Brazilian PCTI when the best results were achieved in terms of developing endogenous technological capacity, but it was marked by the bureaucratic isolation of the decision-making process and the political context of a military dictatorship. Later, with democratization in the mid-1980's, the scientific community emerged as a sector that had resisted dictatorship, which, in the new regime, brought their representative entities and their leaders to a level of political hegemony in the similar PCTI arena that which occurred in the US immediately after World War II and which was responsible for founding the science push paradigm. The result was contempt for state planning in CT\&l because it drew on the experience of the 1970s, and the beginning of a phase in which the science push PCTI model became, beyond a paradigm, a political reference stable subsystem.

At present, other notions need to guide priority setting and government planning in ST\&lin a democratic context, responsiveness and accountability become goals 
for the systemic functioning of any public policy area. The ability of governments to reallocate and redefine priorities is closely associated with their ability to implement the political agenda to which they were elected. No policy area should be reserved for the interests of specific social sectors who would have the privilege of giving a sovereign opinion on what their priorities should be. Especially, when it influences general social dynamics or interests of other sectors of society.

The political and institutional trajectory of the science and technology sector in Brazil was marked by bureaucratic isolation in the 1970s and the argument of expertise in present times. Both end up serving the same purpose: shielding the decisionmaking arena from interests and opinions that broadly express social priorities. In a democratic regime, this implies the ungovernability of the sector, the inability of the state to discard old priorities and take on new ones. Either this ability is allowed to be developed or the decision-making arena of Brazilian CT\&I will remain tied to the times of authoritarianism and political obscurity.

\footnotetext{
Note

1 This work was supported by a grant of the Coordination for the Improvement of Higher Education Personnel - Brazil (CAPES). Financing code: 001. Process 88881.310388 / 2018-01. PRINT / CAPES (Legal Infrastructure for Nanotechnology).
}

\section{REFERENCES}

ALBAGLI, S. Marcos institucionais do Conselho Nacional de Pesquisas. Perspicillum, v. 1, n. 1, p.1-166, 1987.

BALBACHEVSKY, E. Processos Decisórios em política científica, tecnológica e de inovação no Brasil: nova geração da política de ciência, tecnologia e inovação. Brasília: CGEE-MCTI, 2010

BAUMGARTNER, F.R. \& JONES, B.D. Agenda Dynamics and Policy Subsystems. The Journal of Politics, v. 53, n. 4, p. 1044-1074, 1991.

. Positive and Negative Feedback in Politics. In Policy Dynamics. Chicago: The University of Chicago Press, 2002.

BORGES, A. Já não se fazem mais máquinas políticas como antigamente: competição vertical e mudança eleitoral nos estados brasileiros. Revista de Sociologia e Política, v. 18, n. 35, p.167-188, 2010.

BUSH, V. Science: The Endless Frontier. In . Transactions of the Kansas Academy of Science (1903). Washington, D.C.: United States Government Printing Office, 1945.

CAMPOS MUNIZ, N.A. O CNPq e sua trajetória de planejamento e gestão em C\&T: histórias para não dormir contadas pelos seus técnicos (1975-1995). Tese de Doutorado. Brasília: Universidade de Brasília, 2008.

CERVO, A.L. \& BUENO, C. História da política exterior do Brasil. São Paulo: Editora Ática, 1992.

DAGNINO, R. Ciência e tecnologia no Brasil: o processo decisório e a comunidade de pesquisa. Campinas: Editora Unicamp, 2007.

D'ARAUJO, M.C.S. A elite dirigente do governo Lula. Rio de Janeiro: CPDOC/FGV, 2009.

DERENUSSON, M.S. Marco Zero: A criação da FINEP. Inovação em Pauta, n. 11, p.22-24, 2011. 
FERRARI, A.F. O Fundo de Desenvolvimento Técnico-Científico (Funtec) do BNDE. Parcerias Estratégicas, v. 13, n. 26, p.299-322, 2010.

FIGUEIREDO, A. M. C. Resenha de estudos sobre o Executivo. Revista do Serviço Público, v. 55, n. 1-2, p.5-48, 2004.

GEDDES, B. Politician's Dilemma: Building State Capacity in Latin America. Berkeley: University of California Press, 1994.

GUIMARÃES, R. FNDCT: uma nova missão. In S. Schwartzman.( org.). Ciência e Tecnologia no Brasil: política industrial, mercado de trabalho e instituições de apoio. Rio de Janeiro: Fundação Getúlio Vargas, 1995.

HALL, P. A. \& TAYLOR, R. C. Political Science and the Three New Institutionalisms. Political Studies, v. 44, n. 5, p.936-957, 1996.

HELLSTRÖM, T. Techno-scientific Expertise and the Significance of Policy Cultures. Technology in Society, v. 22, n. 4, p. 499-512, 2000.

HIRSCH, A. V., \& SHOTTS, K. W. Policy-Development Monopolies: Adverse Consequences and Institutional Responses. Working Paper n. 3137. Stanford Graduate School of Business, 2014.

JONES, B. D.; BAUMGARTNER, F.R. \& TRUE, J.L. Policy Punctuations: US Budget Authority, 1947-1995. The Journal of Politics, v. 60, n. 01, p.1-33, 1998.

KINGDON, J. W. Agendas, Alternatives, and Public Policies. London: Longman Publishing Group, 2002.

LOUREIRO, M. R.; ABRÚCIO, F. L. \& ROSA, C.A., 1998. Radiografia da alta burocracia federal brasileira: o caso do Ministério da Fazenda. Revista do Serviço Público, v. 49, n. 4, p.46-82.

MARQUES, E.C. Redes sociais e poder no Estado brasileiro: aprendizados a partir das políticas urbanas. Revista Brasileira de Ciências Sociais, v. 21, n. 60, p.15-41, 2006.

MARQUES, P. Sofismas nucleares: o jogo das trapaças na política nuclear do país. São Paulo: Editora Hucitec, 1992.

MOREIRA, I.D.C. A ciência, a ditadura e os físicos. Ciência e Cultura, v. 66, n. 4, p.48-53, 2014.

NUNES, E. O. A gramática política do Brasil: clientelismo e insulamento burocrático. Rio de Janeiro: Zahar, 1997.

OLIVIERI, C. Política, burocracia e redes sociais: as nomeações para o alto escalão do banco central. Revista de Sociologia e Política, v. 29, n. 29, p. 147-168, 2007.

PACHECO, C.A. As reformas da política nacional de ciência, tecnologia e inovação no Brasil (19992002). Documento preparado para Comisión Económica para América Latina y el Caribe (CEPAL), 2003.

PIERSON, P. The Study of Policy Development. Journal of Policy History, v. 17, n. 1, p. 34-51, 2005.

ROSA, L.P. A Física entre a guerra e a paz: reflexões sobre a responsabilidade social da ciência. Ciência e Cultura, v. 57, n. 3, p.40-43, 2005.

SKOCPOL, T. Bringing the State back- Strategies of Analysis in Current Research. In P. Evans, P.; D. Rueschmeyer \& Scokpol, T. (orgs.) Bringing the State back in. New York: Cambridge University Press, 1985.

. Protecting Soldiers and Mothers: The Political Origins of Social Policy in the United States. Cambridge, MA: Harvard University Press, 1995.

SCHNEIDER, B. R. Burocracia pública e política industrial no Brasil. São Paulo: Editora Sumaré, 1994. 
SCHWARTZMAN, S. Formação da comunidade científica no Brasil. Rio de Janeiro: Companhia Editora Nacional, 1979. . Um espaço para a ciência: a formação da comunidade científica no Brasil. Rio de Janeiro: Companhia Editora Nacional, 2001

SOBRAL, F. A. F. Qualidade acadêmica e relevância social e econômica da educação superior. Cadernos Cedes, v. 29, n. 78, p. 227-241, 2009.

SOLLA PRICE, D. J. Little Science, Big Science. New York: Columbia University Press, 1963.

VELHO, L. Formação de doutores no país e no exterior: estratégias alternativas ou complementares? Dados, v. 44, n. 3, p. 607-663, 2001.

2010. Christopher Freeman - The Determinants of Innovation. Revista Brasileira de Inovação, v. 9, n. 2, p.215-230.

. Conceitos de ciência e a política científica, tecnológica e de inovação. Sociologias, v. 13, n. 26, p.128-153, 2011.

VIDEIRA, A.A.P. 25 anos de MCT: raízes históricas da criação de um ministério. Brasília: CGEEMCTI, 2010.

VIEIRA, C.L. \& VIDEIRA, A.A.P. História e historiografia da Física no Brasil. Fênix, v. 4, n. 3, p. 1-27, 2007. 